\title{
UPAYA MENGOPTIMALKAN BIMBINGAN KONSELING UNTUK MENGATASI PERILAKU MENYIMPANG SISWA (SISWA YANG MEROKOK DI SEKOLAH)
}

\author{
Betty Sinambela \\ Surel: bettysinambela12@gmail.com
}

\begin{abstract}
Abstrak
Penelitian ini bertujuan untuk mengetahui: sejauh mana Upaya Mengoptimalkan Bimbingan Konseling Untuk Mengatasi Perilaku Menyimpang Siswa (Siswa Yang Merokok Di Sekolah). Penelitian ini merupakan penelitian kualitatif. Subjek penelitian ini adalah Murid-Murid Kelas XII SMA N 3 Bagan Sinembah. Tempat penelitian dilakukan di SMAN 3 Bagan Sinembah Kecamatan Bagan Sinembah yang beralamat di Bortrem Jaya Kepenghuluan Bagan Sinembah Kec.Bagan Sinembah. Adapun metode pengumpulan datanya menggunakan teknik, observasi,dokumentasi dan diskusi. Data dianalisis dengan deskriptif kualitatif. Hasil penelitian menunjukkan bahwa: Upaya Mengoptimalkan Bimbingan Konseling Untuk Mengatasi Perilaku Menyimpang Siswa (Siswa Yang Merokok Di Sekolah) bisa di katakan cukup berhasil.
\end{abstract}

Kata kunci : Upaya, Bimbingan Konseling, Perilaku Menyimpang

\section{PENDAHULUAN}

Hidup manusia dalam perkembangan dipengaruhi oleh halhal yang berasal dari dalam diri sendiri, dan faktor-faktor yang berasal dari luar diri pribadinya. Diri pribadi manusia umumnya terdiri dari tiga aspek yaitu, rasionya atau aspek kogngit, emosinya atau aspek afektif, dan yang ketiga merupakan hasil penyerasian antara aspek afektif atau yang disebut aspek konatif atau kehenda manusia (Soekanto, 2004). Perilaku menyimpang yang melanda masyarakat, termasuk juga kalangan siswa tau pelajar umumnya dipengaruhi oleh faktor-faktor di atas. Pada dasarnya perilaku menyimpang disebabkan oleh proses sosialisasi yang tidak sempurna atau tidak berhasil. Proses sosialisasi ini tidak berhasil karena seseorang mengalami kesulitan dalam komunikasi ketiak bersosialisasi. Artinya, individu tersebut tidak mampu mendalami norma-norma masyarakat yang berlaku, adanya ketidakpercayaan diri dari individu tersebut, dan karena ia tidak memiliki kemampuan untuk bersosialisasi.

Perilaku menyimpang dapat terjadi di mana-mana dan kapan saja, baik di sekolah, keluarga, maupun dalam kehidupan dimasyarakat. Biasanya tingkah laku menyimpang ini dilakukan olah kalangan remaja. Karena pada tahap ini remaja masih mencari jati dirinya yang ideal menurutnya, sehingga tidak jarang yang mereka lakukan adalah hal-hal yang menyimpang dari kebiasaan yang berlaku dalam pandangan masyarakat umum. Dalam teori peteotologi sosial yang menyatakan 

bahwa tidak ada keadaan atau perilaku yang betul-betul normal secara ideal, tetap yang ada yaitu bahwa keadaan antara normal dan abnormal. Oleh karena itu, batasan tentang tingkah laku menyimpang memiliki rentang yang cukup luas. Wujud dari tingkah laku menyimpang itu dapat bermacam-macam mulai dari jenis yang tergolong masih ringan dan hingga yang berat.

Banyak faktor atau sumber yang menyadi penyebab timbulnya perilaku menyimpang, baik yang berasal dari dalam diri individu maupun berasal dari luar diri individu yang bersangkutan. Maka di sini akan di bahas apa yang di maksud dengan tingkah laku menyimpang, bentukbentuk tingkah laku menyimpang tersebut dan usaha yang dilakukan untuk menanggulanginya.

Pendidikan nasional berfungsi mengembangkan kemampuan dan membentuk watak serta peradaban bangsa, bertujuan untuk berkembangnya potensi peserta didik agar menjadi manusia yang beriman dan bertakwa kepada Tuhan yang Maha Esa, berakhlak mulia, sehat, berilmu, cakap, kreatif, mandiri, dan menjadi warga negara yang demokratis serta bertanggung jawab".

Penyelenggaraan pendidikan secara formal adalah sekolah. Sekolah merupakan lembaga pendidikan kedua tempat anak berlatih dan megembangkan kepribadiannya setelah dirumah tangga. Dalam lingkungan sekolah ada empat kategori guru yaitu; guru bidang studi, guru praktek, guru kelas, dan guru pembimbing. Guru pembimbing melaksanakan tugas dengan memberikan layanan bimbingan dan konseling. Memperkembangkan diri secara optimal sesuai dengan tahap perkembangan dan predisposisi yang dimilikinya (seperti kemampuan dasar dan bakatbakatnya), berbagai latar belakang yang ada (seperti latar belakang keluarga, pendidikan, status sosial dan ekonomi), serta sesuai dengan tuntutan positif lingkungannya.

Program bimbingan dan konseling di sekolah meliputi 6 bidang yaitu bidang bimbingan pribadi, bimbingan sosial, bimbingan belajar, bimbingan karir, bimbingan kehidupan berkeluarga dan bimbingan keagamaan. Untuk melaksanakan keenam bidangbidang tersebut diwujudkan dalam bentuk layanan yaitu: Layanan orientasi, layanan informasi, layanan penempatan dan penyaluran, layanan penguasaan konten (pembelajaran), layanan konseling individual, layanan bimbingan kelompok, layanan konseling kelompok, layanan konsultasi dan layanan mediasi. Dalam pelaksanaan kesembilan jenis layanan tersebut, guru pembimbing mempunyai enam kegiatan pendukung untuk kelancaran pelaksanaan layanan yaitu; Aplikasi instrumentasi, himpunan data, konferensi kasus, kunjungan rumah dan alih tangan kasus serta terapan kepustakaan. 
Betty Sinambela : Upaya Mengoptimalkan Bim ...

Pelayanan konseling mengemban sejumlah fungsi yang hendak dipenuhi melalui pelaksanaan kegiatannya untuk semua klien. Fungsi-fungsi tersebut adalah fungsi pemahaman, fungsi pencegahan, fungsi pengentasan, dan fungsi pemeliharaan dan pengembangan.

Fungsi pencegahan tersebut merupakan usaha pencegahan terhadap timbulnya masalah. Menurut Horner dan McElhany fungsi pencegahan adalah upaya mempengaruhi dengan cara yang positif dan bijaksana lingkungan yang dapat menimbulkan.

Bimbingan dan konseling merupakan proses pemberian bantuan dengan tatap muka langsung antara guru pembimbing dengan siswa yang memungkinkan peserta didik mampu mengenal dan menerima diri sendiri,serta mengenal dan menerima keputusan, mengarahkan dan mewujudkan diri secara efektif dan produktif sesuai dengan peranan yang diinginkannya dimasa depan.

Adapun rumusalan masalah penelitian ini adalah: (1) Apa yang dimaksud dengan prilaku menyimpang, (2) Apa faktor penyebab dari perilaku menyimpang, (3) Upaya apa yang hasrus dilakukan untuk mencegah dari perilaku menyimpang.

\section{METODE PENELITIAN}

Metode penelitian yang dianggap tepat adalah metode penelitian tindakan yang difokuskan pada situasi kelas yang lebih dikenal dengan Penelitian Tindakan Kelas (PTK) atau Classrrom Action Research (CAR). Sukardi (2004) mengungkapkan bahwa penelitian tindakan pada umumnya sangat cocok untuk meningkatkan kualitas subjek yang hendak diteliti. Sependapat dengan hal ini Madya (1994) mengungkapkan bahwa penelitian tindakan yang dimaksudkan untuk meningkatkan praktik tertentu ke dalam situasi kerja tertentu.

Prosedur yang digunakan dalam penelitian ini, terdiri dari dua siklus dengan tahap-tahap kegiatan yang ditempuh pada tiap siklus meliputi empat kegiatan, yaitu: (1) Tahap perencanaan tindakan (plan), (2) Tahap
pelaksanaan tindakan (action), (3) Tahap pengamatan (Observation), (4) Tahap perenungan (Reflective).

\section{HASIL PENELITIAN DAN PEMBAHASAN}

Berdasarkan permasalahan melalui data pada observasi awal, kemudian dibuat perencanaan tindakan untuk siklus I. Adapun tahap perencanaan tindakan untuk siklus I adalah:
a. Menyusun rencana pembelajaran
b. Membuat lembar observasi
c. Mempersiapkan foto untuk dokumentasi.

\section{Pada Pertemuan pertama} Sebelum pelajaran dimulai, penulis memangil para siswa yang merokok disekolah dan memberinya peringatan 
agar tidak merokok dilingkungan sekolah.

Setelah melakukan tindakan maka peneliti melakukan Observasi atau pengamatan terhadap siswa yang merokok dilingkungan sekolah, dan ternyata penulis masih menemukan siswa yang merokok di lingkungan sekolah.

Berdasarkan hasil penelitian pada siklus I diketahui bahwa para siswa masih ada yang merokok dilingkungan sekolah, selanjutnya peneliti kembali memangil siswa tersebut kenapa masih merokok disekolah, para siswa pun menjawab dari pertanyaan tersebut dan akhirnya peneliti mengatakan bahwa jika berbuat lagi maka akan dipangil orang tuanya dan akan dikeluarkan dari sekolah. Karena sebelumnya sudah diberikan peringatan kepada siswa tersebut.

Selanjutnya, pada siklus ke II di lakukan tahap perencanaan, yaitu :
a. Menyusun
rencana pembelajaran.
b. Membuat lembar observasi
c. Mempersiapkan foto untuk dokumentasi

Selama hampir 6 minggu penulis mengamati dari hasil tindakan pertama, ternyata hasilnya cukup memuaskan, penulis dalam kesempatan apel senin juga selalu mengingkatkan kepada siswa agar tetap mengikuti peraturan disekolah dan tidak melakukan perbuatan yang buruk seprti merokok disekolah.

Dalam pengamatan yang penulis lakukan ternyata sudah mengalami peningkatan yang baik para siswa sudah tidak berani lagi merokok dilingkungan sekolah.

Refleksi

Dengan demikian hasil penelitian sudah mencapai target yang ditetapkan dan penelitian ini berhenti pada siklus II,

\section{Pembahasan}

Dalam penelitian ini penulis mendapatkan hasil penelitian bahwa siswa yang merokok disekolah dikarenakan ada beberapa faktor di antaranya :

a. Peraturan sekolah kurang tegas

b. Para siswa tidak diberi peringatan tentang akibat dari perbuatannya

c. Para guru hendaknya ikut aktif memberikan nasehat, bahwa merokok bukan merupakan perbuatan yang baik karena dapat merugikan kesehatan sendiri juga berpengaruh kepada teman yang lainnya.

d. Bimbingan siswa harus lebih ditingkatkan lagi.

Pada siklus 1 penulis mendapatkan bahwa masih ada siswa yang merokok di lingkungan sekolah, meskipun sebenarnya diluar sekolah juga merupakan perbuatan yang tidak baik karena hal tersebut dapat merusak kesehatan siswa yang masih remaja. Penulis menemukan ada lebih kurang 10 siswa yang merokok dilingkungan sekolah, akhirnya penulis memanggil siswa tersebut dan memberikan bimbingan serta menjelaskan aturan-aturan dalam 
lingkungan sekolah. para penulis juga mengatakan bahwa jika perbuatan nya tetap dilakukan maka akan dikeluarkan dari sekolah. akhinya para siswa meminta maaf dan berjanji tidak akan mengulanginya lagi.

Pada siklus II penulis kembali melakukan pengamatan dan diskusi dengan guru-guru serta para siswa apakah ada yang melihat siswa yang berani merokok di lingkungan sekolah, dan ternyata hasilnya menunjukkan bahwa tidak ada lagi siswa yang berani merokok dilingkungan sekolah, kecuali diluar dilingkungan sekolah masih ada yang melihat, tapi disini penulis hanya fokus kepada dilingkungan sekolah saja karena merupakan kewajiban dari pihak sekolah untuk menjaga siswanya.

Dengan demikian penelitian ini cukup sampai pada siklus II saja karena target nya sudah terpenuhi.

\section{SIMPULAN}

Berdasarkan pembahasan di atas, maka dapat diambil beberapa kesimpulan, yaitu:

a. Perilaku menyimpang merupakan bentuk perilaku yang dilakukan oleh seseorang siswa yang tidak sesuai dengan norma dan nilai sosial yang berlaku dalam masyarakat, baik secara langsung maupun secara tidak langsung akan mempengaruhi belajarnya yang pada akhirnya menurutnya prestasi yang diperoleh di sekolah

b. Jenis-jenis perilaku menyimpang yang terjadi di kalangan siswa yang dapat mempengaruhi prestasi belajarnya antara lain: tawuran, penyalahgunaan narkotika, obat-obatan terlarang, dan minuman keras, serta tidak criminal dan penyimpangan seksual yang dapat berakibat pada penularan penyakit HIV/AIDS.

c. Upaya pencegahan perilaku menyimpang secara khusus dapat dilakukan dalam lingkungan keluarga dan lingkungan tempat tinggal.

d. Upaya yang dilakukan guru pembimbing untuk mencegah perilaku menyimpang diantaranya memberikan bimbingan yang berkelanjutan, menerapkan peraturan sekolah seperti disiplin, berpakaian rapi, tidak bolos sekolah.

\section{DAFTAR RUJUKAN}

Al-Mighwar, M. 2006. Psikologi Remaja Petunjuk bagi Guru dan Orangtua. Bandung: Pustaka Setia.

Hamid Hasan, Said, Dkk. 2010. Pengembangan Pendidikan Budaya Dan Karakter Bangsa. Jakarta: Badan Penelitian dan Pengembangan Pusat Kurikulum Kementrian Pendidikan Nasional.

Mailani, E., \& Sutrisno, A. 2015. Peranan Bimbingan Konseling Terhadap Penyelesaian KasusKasus Yang Terjadi Pada Siswa Di Smp Negeri 35 Medan. ELEMENTARY SCHOOL 
JOURNAL PGSD FIP UNIMED, 3(2).

Maryati, Kun dan Juju Suryawati. 2007. Sosiologi 1 untuk SMA dan MA Kelas X. Jakarta: Exis.

Mudjiran, dkk. 2008. Buku Ajar: Perkembangan Peserta Didik. Padang: UNP Press.

Muin, Idianto. 2006. Sosiologi SMA/MA Untuk Kelas X. Jakarta: Erlangga. 